\title{
PEMBELAJARAN SEJARAH PERADABAN ISLAM MELALUI ONLINE GAME AND QUIZ
}

\author{
Isti'anah Abubakar ${ }^{1}$
}

\begin{abstract}
History of Islamic civilization is a subject which gives advantages for all people who learn it, but unfortunately it can't be realized in the results of learning. The impression of monotonous, static, bored, and saturated is responses that always appears when people learning history. Online game and quiz is application that helped by web and internet access which enable students and teachers to learn History of Islamic civilization easily. This application indirectly make easy students and teachers to minimize the main problems in learning History of Islamic Civilization, they are complexity of material and students' overfullness. As one alternative in learning History of Islamic civilization, this application still needs improvement. Sharing between teachers of History of Islamic civilization is definitely expected to make this application better.
\end{abstract}

Keywords : Online game and Quiz and learning of History

\section{A. Pendahuluan}

Sejarah Peradaban Islam (selanjutnya disebut SPI) merupakan matakuliah yang selalu diberikan di PTAIN/PTAIS. Matakuliah ini diberikan agar mahasiswa dapat meneladani dan mengambil ibrah dari peristiwa sejarah yang telah terjadi sehingga mampu menciptakan peradaban Islam yang gemilang seperti masanya dulu. Sejarah merupakan bagian dari ilmu sosial yang mempunyai peranan yang sangat penting dalam rangka menumbuhkan rasa nasionalisme diniyyah, hal ini karena sejarah merupakan kajian ilmu yang menjelaskan tentang peristiwa masa lampau yang disertai dengan fakta-fakta yang jelas. Selain itu mata pelajaran sejarah memiliki kegunaan yang cukup bermakna seperti kegunaan edukatif (pendidikan), instruktif (pemberi pelajaran), inspiratif (pemberi ilham), rekreatif (pemberi kesenangan), inovatif (memberi wawasan maju), bahkan dapat memberikan kegunaan ethis dan pedoman moral dalam bermasyarakat dan bangsanya. Namun demikian kegunaan yang sedemikian saratnya belum mampu diinternalisasikan

1 Dosen Fakultas Ilmu Tarbiyah Dan Keguruan Universitas Islam Negeri Maulana Malik Ibrahim Malang Jl. Gajayana No. 50 Malang 65144 
ke dalam diri peserta didik meskipun materi SPI bersifat repeatation (pengulangan). Hal ini bisa dilihat dari content SPI yang sejak tingkat Ibtidaiyah sampai Perguruan Tinggi memiliki kesamaan namun berbeda dalam hal penyampaiannya. (Mahrus) Meskipun SPI diberikan sejak tingkat Ibtidaiyah sampai Perguruan Tinggi namun belum mampu menumbuhkembangkan rasa cinta terhadap tanah air dan bangsa dan agama diperkuat dengan kurang mampunya nilai-nilai tersebut diimplementasikan oleh pengajar sejarah secara maksimal. Hal ini terlihat dari masih lemahnya respon, motivasi anak didik dalam mempelajari sejarah baik dikarenakan karakteristik sejarah itu sendiri maupun strategi pembelajaran yang digunakan oleh pendidik. (Kompas, 15 Januari 1996).

Hasil pengamatan peneliti - selama mengampu matakuliah SPI motivasi mahasiswa dalam mengikuti SPI masih rendah. Hal ini juga dikuatkan data yang merupakan hasil observasi mahasiswa terkait persepsi mahasiswa UIN Maliki Malang terhadap SPI dan diperkuat dengan hasil diskusi dengan sejawat sesama pengampu SPI di fakultas lainnya. (Observasi Mahasiswa 2011) Hasil yang didapat sungguh mengejutkan, dimana mayaoritas mahasiswa "mengaku terpaksa "mengambil matakuliah SPI. Hasil observasi tersebut menunjukkan bahwa rendahnya motivasi mahasiswa mengikuti matakuliah SPI dengan beberapa indikator, (1)seringnya mereka tidak mengikuti matakuliah SPI, kalaupun mereka mengikuti matakuliah SPI hanya sebatas pada formalitas tanpa mau bersikap aktif dalam pembelajaran SPI. Kondisi ini dalam observasi awal penulis disebabkan 2 hal yaitu (a) pembelajaran yang masih monoton, konvensional yang semakin menjauhkan mahasiswa dari kesenangannya akan sejarah, (b) kurangnya matakuliah yang menjadikan SPI sebagai prasyarat, sehingga mindset mereka adalah hanya untuk memenuhi SKS dimana SPI merupakan matakuliah yang wajib diberikan di PTAIN/PTAIS, (2) kurangnya implementasi SPI yang dikaitkan dengan kehidupan sehari-sehari sehingga kesan "tidak membutuhkan SPI" sangat kental terlihat selama proses pembelajaran SPI. Indikator yang sangat terlihat terkait rendahnya motivasi mahasiswa dalam mengikuti SPI adalah kurang aktifnya mereka dalam mengikuti desain pembelajaran yang dibuat oleh pengajar, seperti keengganan untuk bertanya, membaca buku dan lainnya.

Sebagai pengajar- tentu saja - kondisi ini sangat meresahkan, mengingat urgensitas sejarah sebagai mother of science yang berperan 
penting dalam membangun karakter bangsa. (Kochhar, 2008: 1) Untuk itu diperlukan kreativitas dalam menyajikan materi SPI salah satunya dengan memanfaatkan dengan memanfaatkan multimedia sebagai sarana utama dalam melakukan proses pembelajaran. Pilihan ini didasarkan pada, (1) sudah mulai menjamurnya pembelajaran yang menggunakan multimedia, (2) kesenangan mahasiswa dengan permainan yang bisa diarahkan dan diberdayakan, (3) UIN Maliki Malang yang telah mampu memfasilitasi pembelajaran menggunakan multimedia, seperti internet, dll. (wawancara dengan staf LPSI UIN Maliki Malang) Untuk itu dibutuhkan concern dalam mengembangkan proses pembelajaran yang lebih mendayagunakan sarana, fasilitasyang telah tersedia dalam hal ini di UIN Maliki Malang. Berdasarkan paparan di atas, maka kajian ini dimaksudkan untuk sharing terkait modifikasi pembelajaran pada matakuliah SPI yang telah dilakukan sehingga memperkaya wawasan pembelajaran disamping meningkatkan keaktifan dan kemandirian mahasiswa dalam mempelajarinya.

Online game and Quiz merupakan kumpulan pertanyaan yang disusun berdasarkan materi SPI yang telah disesuaikan dengan silabus. Pertanyaan yang dimaksud akan dibentuk berdasarkan level-level, mulai rendah (terkait materi awal SPI) sampai tinggi ( mencakup keseluruhan materi SPI). Penggunaan Online Game and Quiz ini secara tidak langsung akan merangsang keaktifan mahasiswa dalam pembelajaran SPI, untuk itu mahasiswa harus terlebih dahulu menyiapkan materi terkait dengan level-level yang telah diformat atau diprogramkan.

\section{B. Pembahasan}

\section{Pembelajaran Sejarah : Konsep dan Karakteristiknya}

Kompleksitas dan saratnya makna sejarah memerlukan pembelajaran yang juga bermakna. Pembelajaran identik dengan kegiatan yang dilakukan guru untuk mampu mendesain pengalaman belajar siswa sesuai dengan karakteristik siswa dan mata pelajarannya. Hal ini berarti bahwa, guru harus memahami betul apa yang harus diketahui , dilakukan dan akan menjadi apa nantinya siswa tersebut dengan mata pelajaran yang diberikan itu. (Kochhar, 2008: 27) 
Konsep dan Karakteristik Pembelajaran Sejarah

Terdapat 8 konsep pokok yang utama dalam pembelajaran sejarah yang diungkapkan Richard Green (2009 : 113) yaitu: waktu, situasi/peristiwasejarah dan karakteristiknya (pengertian akan periode tertentu), kontinuitas, perubahan, sebab, konsekuensi/akibat, interpretasi/sudut pandang, bukti sejarah. Adapun apa yang seyogyanya dipelajari dalam sejarah dapat dilihat di bawah ini:

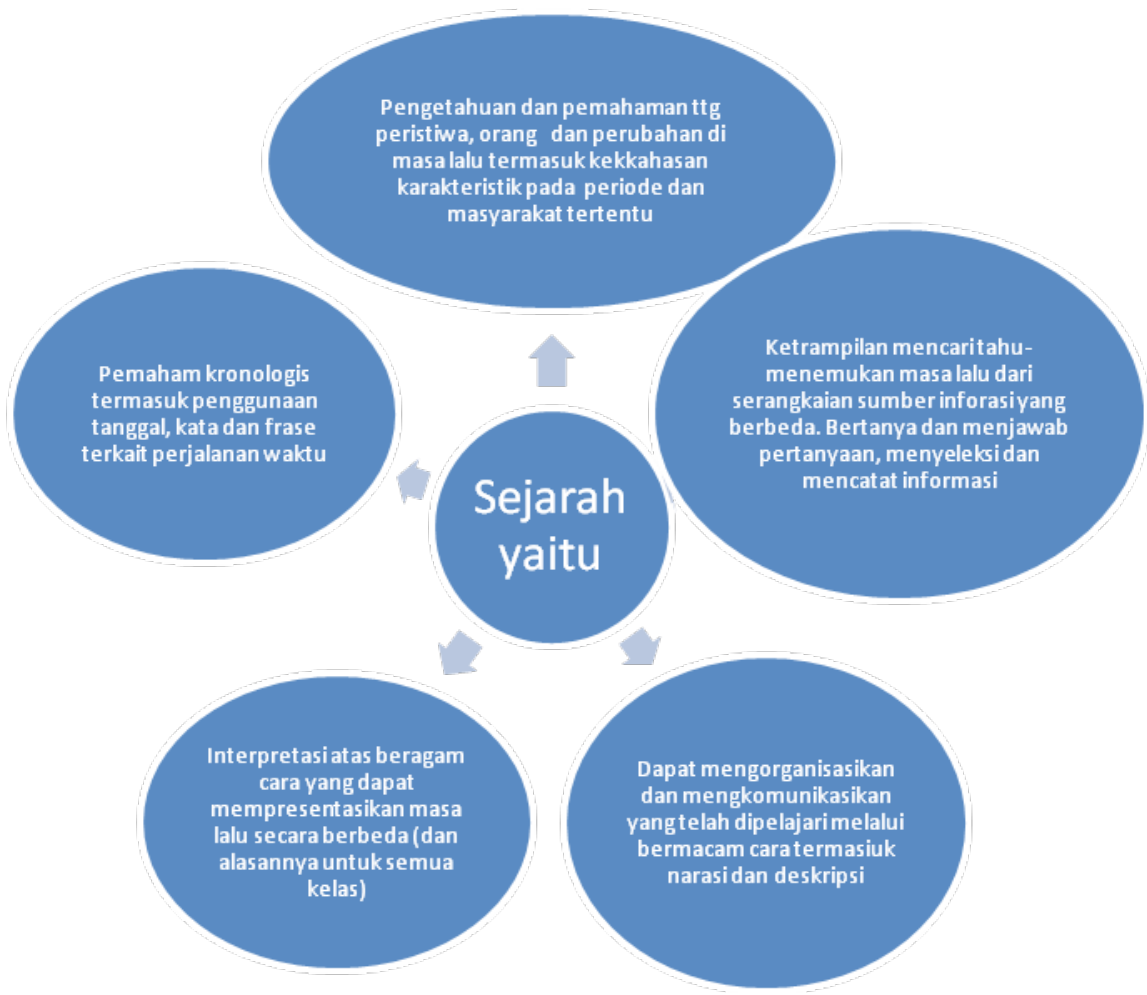

Adapun Kochhar (Kochhar, 2008: 28) mengungkapkan bahwa sasaran umum pembelajaran sejarah sebagai berikut : mengembangkan pemahaman tentang diri sendiri, memberi gambaran yang tepat tentang konsep waktu, ruang dan masyarakat, membuat masyarakat mampu mengevaluasi nilai-nilai dan hasil yang telah dicapai oleh generasinya,mengajarkan toleransi, menanamkan sikap intelektual, memperluas cakrawala intelektualitas, mengajarckan prinsip-prinsip moral, menanamkan orientasi ke masa depan, memberikan pelatihan mental Melatih siswa menangani isu-isu kontroversial, membantu 
mencarikan jalan keluar bagi berbagai masalah sosial dan perseorangan, memperkokoh nasionalisme, mengembangkan pemahaman internasional, mengembangkan ketrampilan-ketrampilan yang berguna.

\section{Materi Sejarah Peradaban Islam di Perguruan Tinggi Islam}

Sejarah peradaban Islam (SPI) di Perguruan Tinggi merupakan matakuliah yang diharapkan mampu menjembatani dan mengkontekstualisasikan data historis sebagai guide line untuk menjalani kehidupan akademik dan sosialnya. Berdasarkan 8 konsep pokok pembelajaran sejarah dan sasaran umumnya serta karakteristik peserta didik di Perguruan Tinggi, maka diperlukan pemetaan dan penentuan materi seperrti apa yang harus diberikan kepada mahasiswa. Bagi mahasiswa Perguruan Tinggi, maka materi SPI idealnya mengacu pada 8 konsep pembelajaran sejarah. Mahasiswa diarahkan untuk memahami tentang waktu, situasi/ peristiwa sejarah dan karakteristiknya (pengertian akan periode tertentu), kontinuitas, perubahan, sebab, konsekuensi/akibat, interpretasi/sudut pandang, bukti sejarah. Selama ini, pembelajaran sejarah terkesan parsial, belum menyentuh ke 8 konsep pembelajaran secara keseluruhan. Mahasiswa sebagai peserta didik yang harus diberdayakan berpikir kritisnya, idealnya mempelajari sejarah berdasar 8 konsep tersebut secara keseluruhan. Berpikir kiritis dalam sejarah lebih mengedepankan pertanyaaan "why" mengapa terjadi peristiwa ini dan itu. Tahapan ini akan bisa dilakukan dengan jika pertanyaan dasar lainnya telah dimiliki. Pertanyaan dasar yang dimaksud adalah, (1) when (kapan), kapankah peristiwa tersebut terjadi, (2) who (siapa), siapakah sosok yang berperan dalam peristiwa tersebut, (3) what (apa), peristiwa apakah yang terjadi pada tahun tersebut, (4) where (dimana), dimanakah kejadian tersebut terjadi, (5) How (bagaimana), bagaimanakah peristiwa tersebut terjadi . Kelima pertanyaan tersbut merupakan pondasi yang harus dikuasai pembelajar sehingga aspek "mengapa" sebagai sebuah rasionalitas dan kontinuitas dapat dipaparkan secara gamblang.

Realitanya, pembelajaran SPI di Perguruan Tinggi masih berkutat pada 5 dasar pertanyaan di atas (what, when, who, where dan How) karena memang mahasiswa belum menguasai materi dasar tersebut. Akibatnya, pembelajaran sejarah SPI di PT masih didominasi oleh repition yang bersifat knowing belum pada tataran understanding apalagi 
Isti'anah Abubakar - Pembelajaran Sejarah Peradaban Islam ...

implementation. Padahal tahapan understanding dan implementation merupakan tahapan yang sangat berperan dalam mewujudkan tujuan pembelajaran sejarah, yaitu menumbuhkan kesadaran dan mampu mengambil ibrah untuk digunakan dalam berkehidupan pada masa kini dan akan datang.

\section{Multimedia Sebagai Media Pembelajaran Interaktif Pengertian Multimedia}

Pembelajaran masa kini setidaknya terdiri dari beberapa komponen berikut, pertama, nilai merentasi kurikulum, kedua bahasa merentasi kurikulum, ketiga,kemahiran berfikis merentasi kurikulum, keempat, kemahiran asas teknologi pendidikan, kelima kemahiran sebagai fasilitator dan pembimbing. (Abd Halim, 2008: 148) Multimedia adalah kombinasi dari komputer dan video sehingga secara prinsip, multimedia merupakan gabungan dari tiga elemen dasar yaitu suara, gambar dan teks. (Mulyanta, 2009: 1) Dan juga menurut Hofsteer (2001) multimedia adapalah pemanfaatan komputer untuk menggabungkan teks grafik, audio, gambar bergerak (video dan animasi) menjadi satu kesatuan dengan link dan tool yang tepat sehingga memungkinkan pemakai multimedia dapat melakukan navigasi, berinteraksi, berkreasi dan berkomunikasi

\section{Manfaat Pembelajaran Berbasis Multimedia}

Isjoni mengutip dari Klien Pridemon (1992) dan Hooper (1992) menyatakan, sudah saatnya pendidik diarahkan mulai belajar kooperatif dalam pembelajaran multimedia, yaitu pembelajarn yang berasas komputer. Ada beberapa keuntungan yang akan didapat bila menggunakan pembelajaran multimedia, yaitu, pertama, adanya ketergantungan dan tanggung jawab dari setiap ahli kumpulan, kedua, adanya interaksi yang promotif dimana usaha seorang individu akan mendukung usaha ahli kumpulan lainnya, ketiga, kesempatan latihan untuk bekerjasama, keempat, pengembangan dan pemeliharaan kumpulan. (Isjoni dan Islamil, 2008: 19) Hal ini juga dikuatkan oleh Abdul Halim bin Tamuri (2008: 144) bahwa manfaat TMK (Teknologi Maklumat dan Komunikasi) atau lebih kita kenal dengan multimedia adalah : 
a. Berupaya meningkatkan kefahaman dan penguasaan pelajar terhadap pelajaran

b. Memberi peluang pembelajaran yang sama kepada semua pelajar yang belpagai keupayaan

c. Meningkatkan motivasi pelajar

d. Membolehkan pembelajaran berkesendirian (individualize learning)

e. Membolehkan pelajar mengkases maklumat yang sukar diperoleh

f. Mewujudkan suasana pembelajaran yang menyeronokkan dan mencabar

Keenam hal diatas menunjukkan bahwa multimedia menjadi sangat urgen untuk dapat gunakan dalam proses pembelajaran. Hal ini juga dikuatkan oleh kajian Maimun Aqsha Lubis (2008) bahwa pemanfaatan multimedia dapat memberi satu sesi pengajaran dan pembelajaran yang lebih menarik, kreatif dan inovatif serta memberi pengalaman belajar dengan lebih berkesan kepada para pelajar. (Isjoni dan M. Arif Islamil, 2008: 166)

\section{Pembelajaran SPI melalui Online Game and Quiz}

Pembahasan ini difokuskan pada 3 hal yaitu (a) deskripsi online game and quiz, memaparkan alasan dan desain online game and quiz, (b) Tampilan online game and quiz

\section{Deskripsi tentang Online Game and Quiz}

Kendala utama pembelajaran sejarah adalah lemahnya penguasaan content dan keaktifan mahasiswa dalam pembelajaran sejarah. Untuk mengatasi kedua hal tersebut, maka online game and quiz yang penulis susun diharapkan mampu menjadi solusi permasalahan umum tersebut. Online game and quiz ini merupakan aplikasi yang didasarkan pada: (a) karakteristik user, karena usernya adalah mahasiswa maka model butir soal yang digunakan disesuaikan dengan karakteristiknya sebagai mahasiswa yang secara mandiri bisa mengeksplorasi kemampuaannya, (b) lemahnya materi SPI yang dikuasai sehingga , peneliti harus bisa mencakup 2 tujuan sekaligus, penguasaan materi dasar dan idealitas pembelajaran SPI bagi mahasiswa, (c) kurangnya keaktifan mahasiswa 
Isti'anah Abubakar - Pembelajaran Sejarah Peradaban Islam ...

dalam mempelajari materi SPI. Adapun desain utama online game and quiz yang digunakan sebagai berikut:

(1) Penggunaan level untuk membedakan materi satu dengan materi yang lain

(2) Adanya time limit yang digunakan untuk tiap levelnya. Waktu yang diberikan untuk tiap levelnya adalah 18 menit dengan asumsi bahwa mayoritas materi sudah dipelajari sebelumnya sehingga aspek memorizing menjadi dasar pemikiran utamanya

(3) Prosedur yang digunakan dalam pelaksanaannya, ketika mahasiswa melebihi time limit yang telah diprogramkan (18 menit untuk tiap levelnya ) maka mahasiswa tidak akan bisa naik ke level berikutnya. Prosedur ini digunakan untuk melatih konsentrasi dan kemandirian mahasiswa dapat lebih ditingkatkan.

(4) Perlu dipahami, bahwa model ini adalah langkah awal untuk menghadirkan model pembelajaran SPI yang lebih menarik bagi mahasiswa. Karena langkah awal, maka masih perlu penyempurnaan -penyempurnaan untuk mendapat hasil yang ideal, meskipun tentu saja ada beberapa keuntungan yang diperoleh. Keuntungan yang dapat dirasakan dengan menggunakan model ini adalah, (a) fokus mahasiswa dapat dibangun dan ditingkatkan, (b) pelaksanaan yang murah meriah dan hasil yang real time sehingga tindak lanjut dapat dilakukan secepatnya. Adapun kekurangannya adalah cycling soal (perputaran soal untuk tiap mahasiswa ) yang belum bisa dilakukan. Dalam artian, bagaimana menghadirkan untuk setiap mahasiswa itu soal yang berbeda tergantung pada siapa yang lebih dulu mengaksesnya. Desain tersebut di atas merupakan kerangka model online game and quiz yang dapat dilihat secara kongrit pada tahap selanjutnya yaitu tahap pembuatan.

\section{Tampilan Online Game And Quiz}

Tampilan model online game and quiz ini terbagi menjadi 3 jenis, (a) tampilan luar, (b) tampilan untuk administrator dalam hal ini pengampu matakuliah, (d) tampilan untuk user. Adapun gambaran detailnya sebagai berikut : 


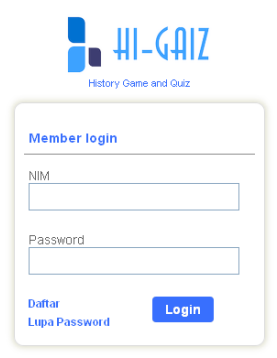

Pada tampilan luar terlihat ada 2 menu untuk dapat mengakses media ini yaitu NIM dan password. Nomor Induk Mahasiswa (NIM) digunakan karena dapat memperkecil kesamaan nama. Bisa saja beberapa mahasiswa memiliki nama yang sama seperi an. Khairul Anam atau yang lainnya. Adapun password merupakan langkah kedua yang mengindikasikan boleh tidaknya mahasiswa mengakses media ini. Sehingga dengan 2 menu di atas, maka ada 2 person yang menginput, pertama, mahasiswa dengan cara memasukkan NIM nya dan, kedua ,pengampu matakuliah yang akan memproses data selanjutnya dan juga berperan sebagai pengecek boleh tidaknya mahasiswa mengakses media terkait adanya 2 kesempatan yang diberikan dalam mengerjakan butir soal di tiap levelnya. Dari aspek penggunaan maka tampilan ini juga diperuntukkan untuk pengampu matakuliah terkait entry maupun editing butir soal yang disediakan, sedangkan untuk mahasiswa hanya untuk mengikuti model yang digunakan. 
1. Tampilan untuk administrator

a. Pengelolaan soal

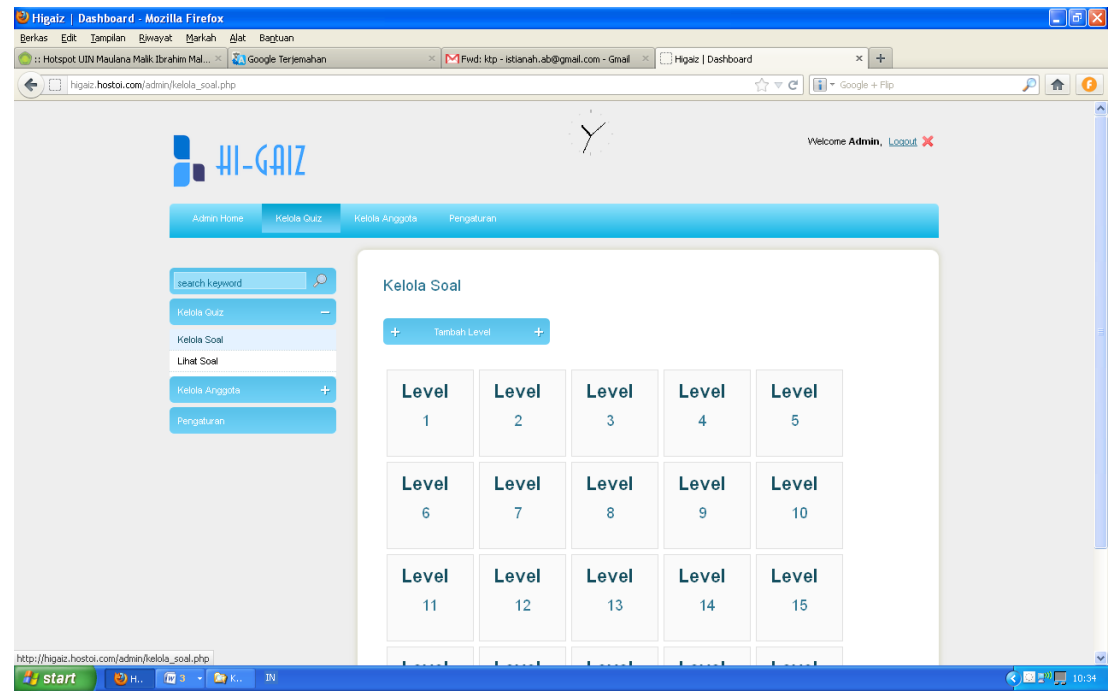

(Tampilan 1)

Terdapat 3 menu diatas, yaitu (1) kelola quiz yang terdiri dari 2 hal, kelola soal dan lihat soal, (2)kelola anggota, dalam hal ini mahasiswa atau bisa diperluas untuk user lain yang berminat dengan SPI, (3) pengaturan, berisi tentang aspek penilaian serta waktu yang dibutuhkan dalam pengerjaan butir soal yang dimaksud. Aspek inilah yang dapt dipergunakan untuk melihat secara real time hasil quiznya. Pada tampilan di atas juga dapat dilhat level yang dipergunakan sebanyak 20 level, namun pada saat ini maka hanya dipergunakan 3 level pertama, sehingga penelitian ini masih berkelanjutan. Adapun tampilan detailnya dapat dilihat dibawah ini: 


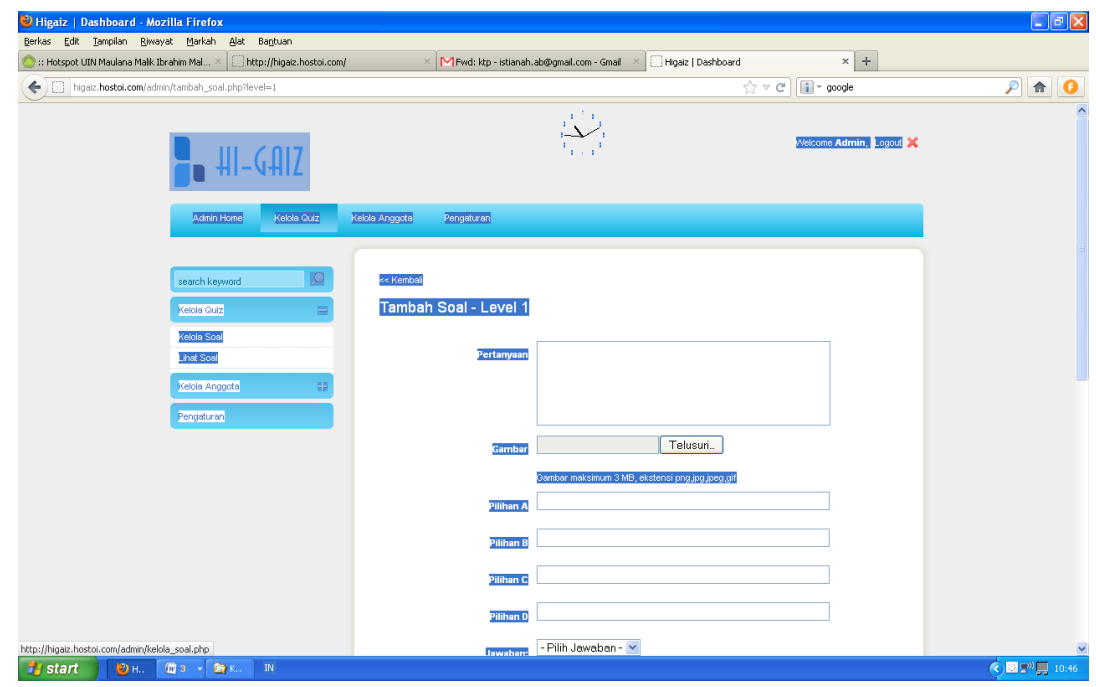

(Tampilan 2)

Tampilan di atas merupakan bank soal yang diperuntukkan untuk pengampu matakuliah sebagai administrator. Tampilan inilah yang dapat dipergunakan untuk mengentry dan bahkan merubah soal sehingga unsur kebaharuan tetap terjaga. Pada aspek pengelolaan soal terlihat 4 menu yang menjadi unsur utamanya, yaitu (a) kotak pertanyaan, pada daerah itulah pertanyaan yang diajukan dituliskan, (b)gambar, merupakan menu yang disediakan untuk memvariasikan soal yang diberikan bisa berupa peta, gambar atau yang lainnya yang merupakan bukti sejarah dimana bukti sejarah adalah salah satu dari 8 konsep pembelajaran sejarah, (c) pilihan jawaban , (d) Kunci jawaban. Dari ke 4 menu yang ada, maka dapat diketahui bahwa terdapat kemudahan dalam mengoreksi hasil sehingga tidak lanjut juga dapat dilakukan secepatnya. Proses entry maupun edit dilakukan dengan tampilan berikut ini: 
Isti'anah Abubakar - Pembelajaran Sejarah Peradaban Islam ...

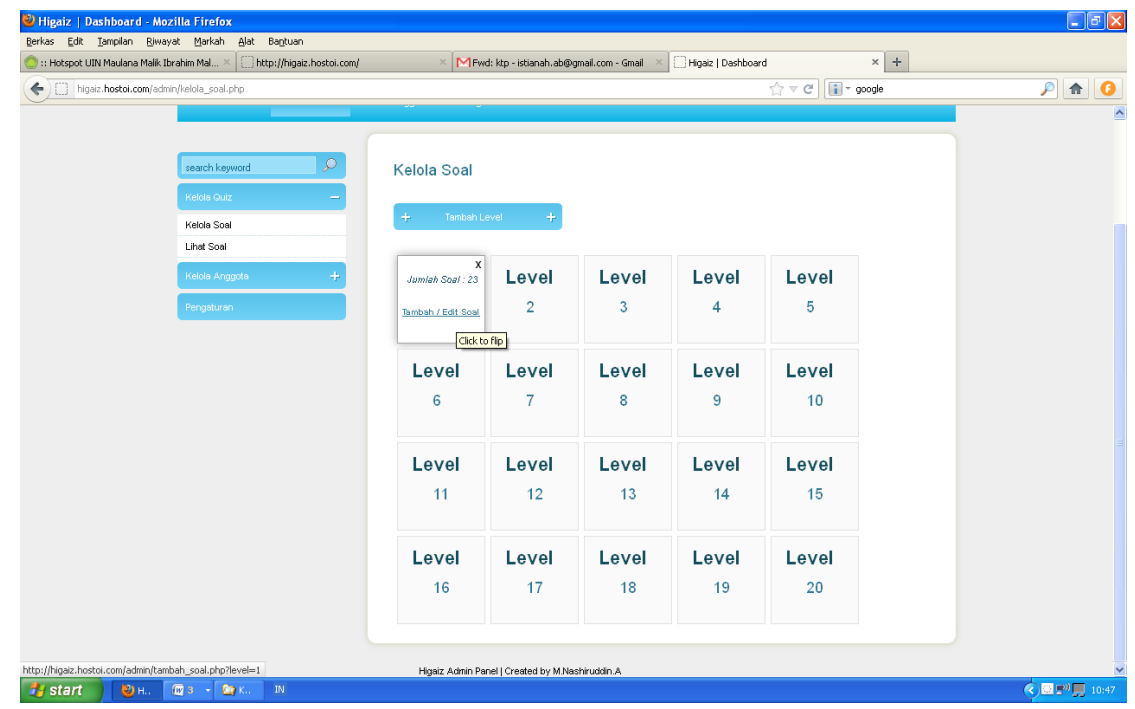

(Tampilan 3 )

Proses entry dan edit soal dapat dilihat pada tampilan di atas.Akan terlihat di setiap levelnya tambah atau edit soal. Ini diperuntukkan untuk administrator dalam mengentry dan mengedit soal yang diberikan. Dengan tampilan ini dapat dilakukan kebaharuan soal sehingga proses dapat dilakukan secara berkelanjutan mengikuti perkembangan yang ada. Untuk melihat keseluruha soal yang telah kita entry maka ditampilkan dengan menu berikut ini :

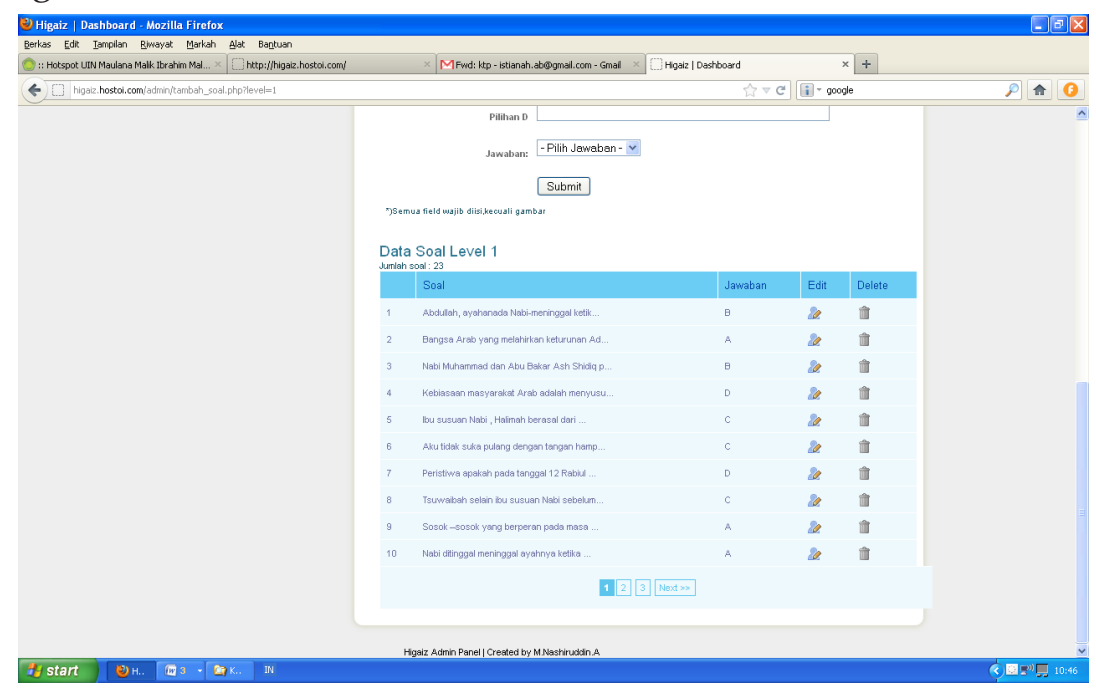

(Tampilan 4) 
Tampilan ini merupakan kelanjutan dari tampilan sebelumnya. Pada tampilan ini lebih difokuskan pada aspek pengecekan soal sehingga kalaupun ada kesalahan dalam penulisan atau jawaban dapat diketahui terlebih dahulu sehingga soal yang akan diupload telah melalui proses yang seharusnya. Adapun tampilan soal yang anntinya akan dikerjakan oleh mahasiswa secara online sebagai berikut :

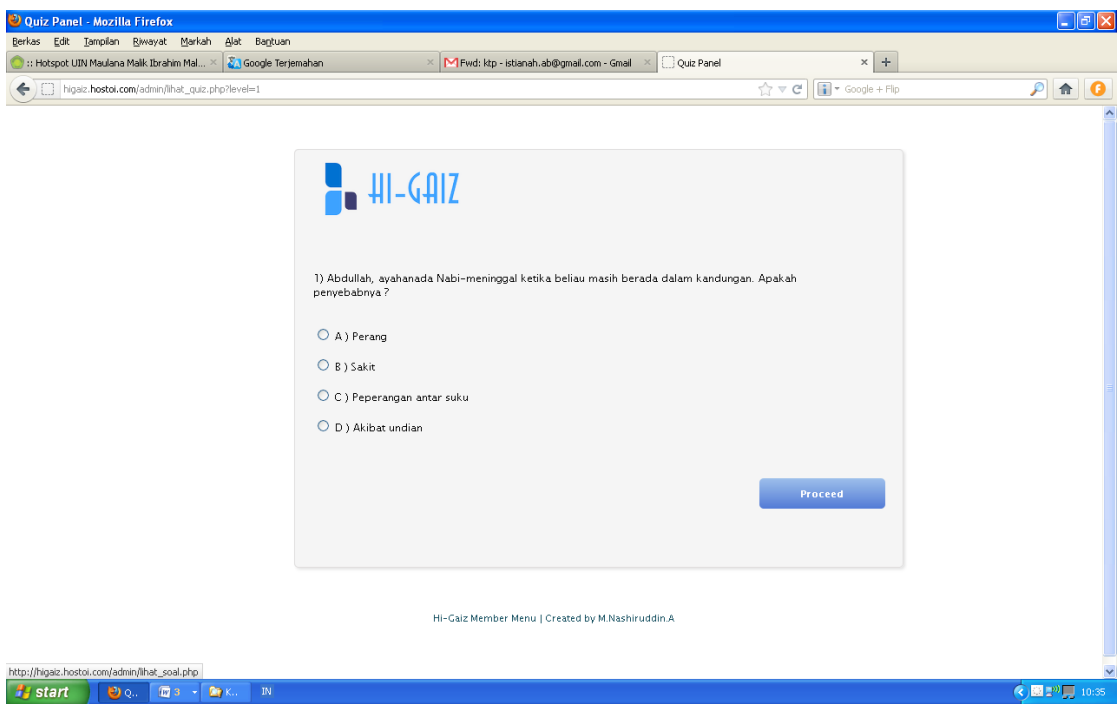

\section{(Tampilan 5)}

Tampilan diatas menunjukkan tampilan soal yang akan dikerjakan user. Sehingga perbedaan dengan tampilan sebelumnya adalah, pada tampilan ini tidak terdapat kunci jawaban, karena memang tampilan ini diperuntukkan untuk user sedangkan tampilan sebelumnya diperuntukkan untuk administrator atau pengelola. Terlihat bahwa model soal yang dipergunakan adalah multiple choice yang merupakan salah satu bentuk soal yang biasanya dipergunakan dalam online game and quiz. Setiap level akan berizi 50 soal atau bisa diprogram lebih dari 50 sehingga fleksibelitas, kreativitas dan kebaharuan terhadap soal yang diberikan dapat dilakukan.

Sedangkan untuk mengetahui data user yang mengikuti model ini dari yang petama sampai yang terakhir menggunakan tampilan berikut ini: 
Isti'anah Abubakar - Pembelajaran Sejarah Peradaban Islam ...

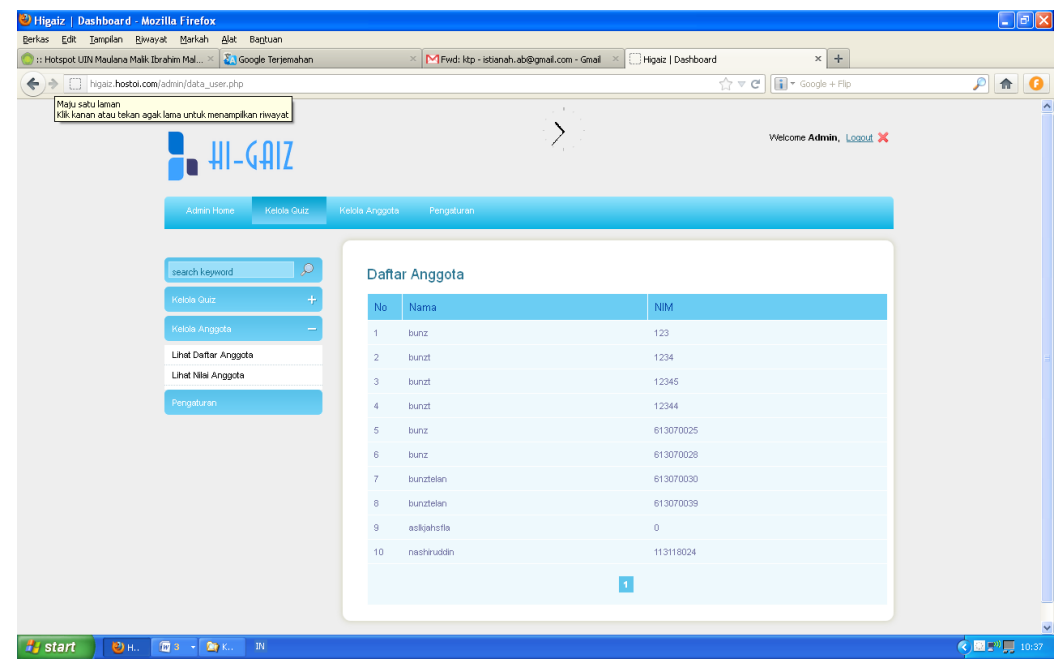

(Tampilan 6)

Pada tampilan di atas, terlihat data user terkait nama dan NIM nya sehingga diketahui siapa saja yang sudah atau belum mengikuti. Sedangkan untuk melihat ketrecapaian hasil mahasiswa dalam mengerjakan kuis ini maka diperlihatkan dengan tampilan berikut ini :

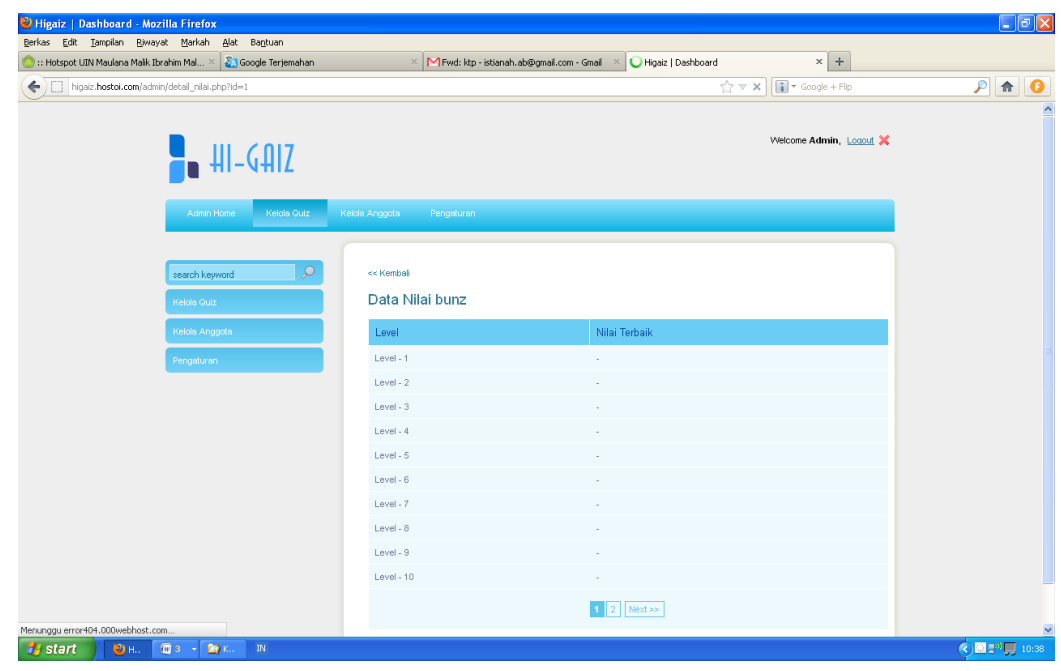

(Tampilan 7)

Pada tampilan di atas, secara real time akan diketahui ketercapaian mahasiswa dalam mengerjakan sehingga tindak lanjutpun dapat segera dilakukan. 
2. Tampilan untuk user

Pada tampilan untuk suser ini hanya terdapat 2 tampilan utama, yaitu tampilan luar dan tampilan soal dimana mahasiswa diminta untuk mengerjakannya. Dua tampilan yang dimaksud sebagai berikut :
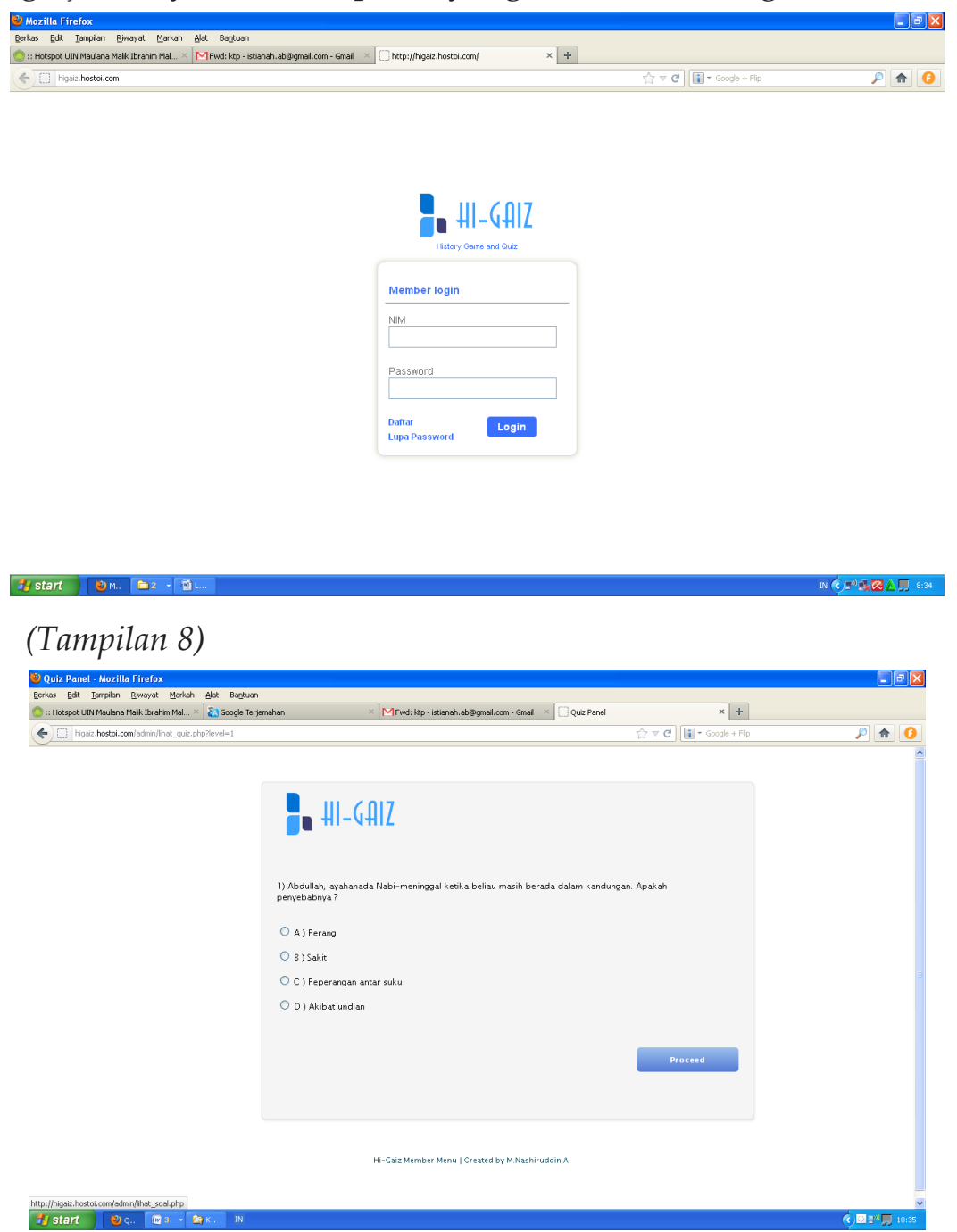

(Tampilan 9)

Berdasarkan tampilan -tampilan di atas, maka dapat di terlihat jelas proses yang akan dilalui baik oleh administrator maupun user dalam hal ini mahasiswa. 
Isti'anah Abubakar - Pembelajaran Sejarah Peradaban Islam ...

\section{Kesimpulan}

Berdasarkan pembahasan di atas, maka dapat disimpulkan sebagai berikut:

1. Perencanaan yang perlu dipersiapkan dalam pembelajaran SPI melalui online game and quiz meliputi 2 hal yaitu model online game and quiz yang dipilih serta content yang disesuaikan dengan silabus pembelajaran

2. Target yang belum terpenuhi merupakan kendala dan evaluasi dalam pembelajaran SPI melalui online game and quiz ini. Setidaknya ada 4 kendala yang teridentifikasi yang lebih bersifat pada teknis paradigmatic. Kendala teknis dapat diantisipasi dengan sosialisasi yang lebih clear dan kongkrit sedangkan kendala paradigmatik lebih diperlukan peningkatan pemahaman mahasiswa akan model pembelajaran SPI yang dikembangkan.

\section{DAFTAR PUSTAKA}

Abdul, Fuad, Mu'jam Mufahrash Li Alfadh AlQuran, Darul Ilmiah, Kairo.

Green, Richard, 2009, Brain Power SD, Aktivitas, Permainan dan Ide Praktis Belajar Ilmu Sosial, Pen, Herlina, Erlangga.

Isjoni, 2008, Pembelajaran Virtual Perpaduan Indonesia-Malaysia, Pustaka Pelajar, Yogyakarta.

Kochhar, S.K, 2008, Pembelajaran Sejarah, Grasindo, Jakarta.

Kemenag RI,2010, Modul Pengembangan Pendidikan Agama Islam di Sekolah, Direktorat Pendidikan Islam, Jakarta.

Mulyanta, St, 2008, Tutorial membangun Multimedia Interaktif, Universitas Atmajaya, Yogyakarta.

Mansur, Ahmad, Suryanegara, Menemukan Sejarah Wacana Pergerakan Islam di Nusantara, Mizan, Bandung, 1995.

Mahasiswa IPS , Persepsi Mahasiswa tentang Sejarah Peradaban Islam, hasil observasi - tugas UAS, tidak dipublikasikan, 2010.

Mahasiswa PAI , Pembelajaran SKI di Madrasah Tsanawiyah, hasil observasi -tugas UTS dan UAS, tidak dipublikasikan, 2012.

Sanjaya, Ridwan, 2008, E learning, Universitas Atmajaya, Yogyakarta 